Working Paper n. 05 - 2015

\title{
GENDER DIFFERENCES IN ATTITUDES TOWARDS COMPETITION: EVIDENCE FROM THE ITALIAN SCIENTIFIC QUALIFICATION
}

\author{
Maria De Paola \\ Dipartimento di Economia, \\ Statistica e Finanza \\ Università della Calabria \\ Ponte Pietro Bucci, Cubo 1/C \\ Tel.: +390984 492459 \\ Fax: +390984 492421 \\ e-mail:m.depaola@unical.it
}

\author{
Michela Ponzo \\ Dipartimento di Scienze, \\ Economiche e Statistiche \\ Università degli Studi di Napoli Federico II \\ Compl. Universitario di Monte Sant'Angelo \\ Via Cintia, 21 - 80126 - Napoli \\ Tel.: +39081675036 \\ e-mail: michela.ponzo@unina.it
}

\section{Vincenzo Scoppa \\ Dipartimento di Economia, \\ Statistica e Finanza \\ Università della Calabria \\ Ponte Pietro Bucci, Cubo 1/C \\ Tel.: +390984 492464 \\ Fax: +390984 492421 \\ e-mail:v.scoppa@unical.it}

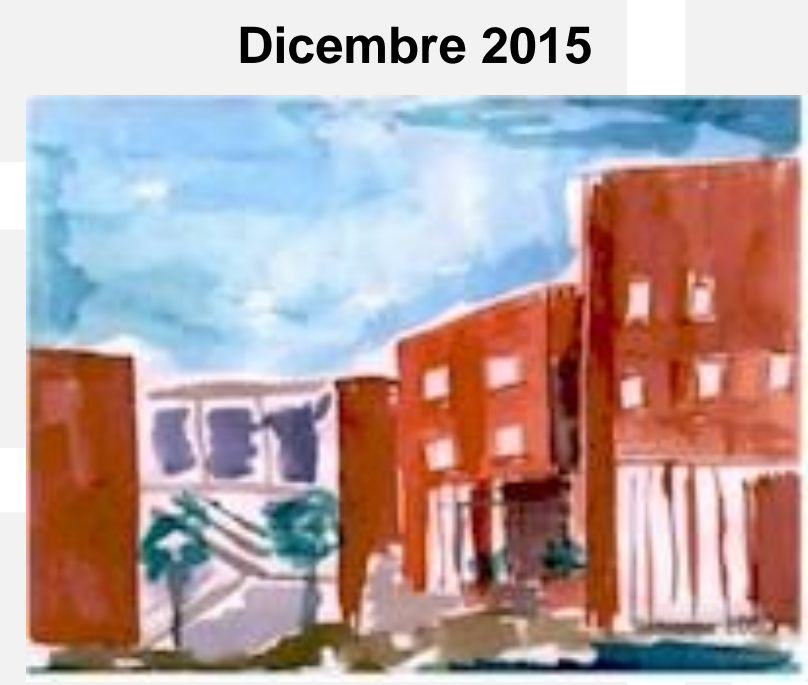




\title{
Gender Differences in Attitudes Towards Competition: Evidence from the Italian Scientific Qualification
}

\author{
Maria De Paola ${ }^{a, b}, \quad$ Michela Ponzo ${ }^{c}, \quad$ Vincenzo Scoppa ${ }^{a, b, *}$ \\ ${ }^{a}$ Department of Economics, Statistics and Finance, University of Calabria \\ ${ }^{b}$ Institute for the Study of Labor (IZA), Bonn \\ 'Department of Economics and Statistics, University of Naples "Federico II"
}

This version: 18 December 2015

\begin{abstract}
We exploit a natural experiment based on the Italian promotion system for associate and full professor positions to investigate gender differences in the willingness to enter competition. Using data on about 42,000 professors and controlling for productivity and a number of individual and field characteristics, we find that females have a lower probability of applying for competition of about 4 percentage points. The determinants of this gap seem to be gender differences in risk-aversion and self-confidence and women's fear of discrimination: the lower tendency to enter competition is especially relevant for women in the lower tail of the distribution of scientific productivity and in fields in which productivity is not easily measurable; furthermore, women are less likely to apply for promotion in fields in which promotions of females in the past were rare.
\end{abstract}

JEL classification: J71; M51; J45; J16; D72, D78

Keywords: Attitudes towards competition; Gender gaps; Risk-aversion; Self-confidence; Discrimination; Academic Promotions; Natural Experiment.

\footnotetext{
E-mail addresses: m.depaola@unical.it (M. De Paola); michela.ponzo@unina.it (M. Ponzo); v.scoppa@unical.it (V. Scoppa).We are very grateful to Antonio Bilotta for helping us with the downloading of data. We would like to thank Manuel Bagues, Giorgio Brunello, Lorenzo Cappellari, Daniele Checchi, Giuseppe Coco, Marco Alberto De Benedetto, Filippo Domma, Francesca Gioia, Sabrina Giordano, Riccardo Lucchetti, Roberto Nisticò, Raffaella Santolini, Stefano Staffolani, Mauro Sylos Labini, Francesca Vocaturo, Natalia Zinovyeva and seminar participants at the AIEL Conference (Pisa, 2014), University of Ancona, Calabria and Florence for useful comments and suggestions.
} 


\section{Introduction}

Gender gaps in economic and social outcomes are pervasive: females earn significantly lower wages, have greater difficulties in getting a job, have lower promotion chances and less access to highly paid jobs and managerial positions ("glass ceiling") and experiment lower political representation (see Altonji and Blank, 1999; Blau and Kahn 2003; Bertrand and Hallock, 2001).

Gender imbalances are particularly striking in Italy. The wages earned by females in the private sector - controlling for education, age and experience - are about 20-25\% lower than males. Women are underrepresented both in the public and in the private sector. Only $20 \%$ of seats in the parliament are held by women and only $3 \%$ of the 50 largest companies' board directors are women. As far as the academia is concerned, women account for $45 \%$ of assistant professors, $34 \%$ of associate professors and only $21 \%$ of full professors (De Paola and Scoppa, 2015).

The traditional explanations for the existence of gender gaps are based on differences in productivity or on gender discrimination: females obtain worse outcomes either because they invest less in human capital, work less hours, are less committed to jobs, or, alternatively, because they suffer from taste or statistical discrimination.

A recent strand of the literature moves beyond the traditional theories by considering that females might have different psychological attitudes and different preferences with respect to males (Bertrand, 2011; Croson and Gneezy, 2009; Azmat and Petrongolo, 2014). A robust evidence shows that females are more averse to risk and are less competitive, have a lower degree of self-confidence and suffer more from receiving negative feedbacks. These psychological differences may be responsible for a significant share of gender gaps in economic outcomes.

Gender differences in attitudes toward competition have received particular attention. A rapidly growing literature shows that females (even those with high abilities) are more reluctant to engage in competitions and when in competition they tend to perform worse than males (Niederle and Vesterlund, 2011).

Most of this literature is based on laboratory experiments. These experiments allow researchers to have full control of important determinants of the phenomenon under study, but have the disadvantages of putting participants in situations that might be far from real-life contexts, of using relatively low stakes and of selecting specific categories of participants (typically, college students), undermining in this way the external validity of the findings.

In one of the most relevant laboratory experiments on this topic, Niederle and Vesterlund (2007) asked participants to solve a series of additions under a competitive (tournament) and noncompetitive (piece-rate) reward system. When asked to choose among incentive schemes, 73 percent of male participants chose the tournament scheme against only 35 percent of females, although males 
and females performed similarly in the proposed tasks. ${ }^{1}$ In another laboratory experiment consisting in solving mazes, Gneezy, Niederle and Rustichini (2003) find that males and females perform similarly in non-competitive environments, but females are much less effective than males in competitive contexts, especially if they have to compete against males. Similar results are found by Gneezy and Rustichini (2004) who measure the performance of 9-10 years old boys and girls in a short distance race: whereas males improve their performance in competitive settings, the opposite happens for females. ${ }^{2}$ Sutter and Glätzle-Rützler (2015) find strong gender gaps in propensity to compete between children aged three to eighteen years.

More contrasting results emerge in field experiments. Whereas some works confirm that in real life situations women underperform relative to men in competitive settings, several other studies do not find any gender difference in performance (see Delfgaauw et al., 2013; Lavy, 2012; Jurajda and Munich, 2011; Ors, Palomino and Peyrache, 2013).

Evidence from the field on female preferences for competition is scant. Flory, Leibbrandt and List (2015) in a natural field experiment randomize 7,000 job-seekers into different compensation regimes and find that females tend to shy away from competitive settings, although gender differences vary according to the type of job. De Paola, Gioia and Scoppa (2014) - in a field experiment designed to neutralize gender differences in self-confidence, in risk attitudes and in preferences for feedbacks on relative performance - find that females are as likely as males to enter competition.

We study the issue of willingness to compete in a real labor market and investigate the propensity of men and women to enter in competition relying on a natural experiment based on the Italian academic promotion system for associate and full professor positions, involving nearly 43,000 academics.

Currently, individuals aiming to be promoted to associate or full professor positions in Italy have first to participate in a national-wide competition, "National Scientific Qualification" or "Abilitazione Scientifica Nazionale" (ASN in brief). Evaluations of candidates are conducted separately in 184 scientific sub-fields by committees composed by 5 members randomly selected among full professors. Each committee evaluates candidates' publications and CV and awards the National Qualification to candidates reaching a minimum threshold. No teaching lecture or seminar presentation is required to candidates. Candidates who fail to obtain the qualification are not allowed to take part in the competition for the ASN in the following two years.

\footnotetext{
${ }^{1}$ Buser, Niederle and Oosterbeek (2014) show that, among secondary school students in the Netherlands, the measure of competitiveness proposed by Niederle and Vesterlund (2007) is strongly and positively correlated with choosing math and science academic courses. In their study competitiveness explains a large part of the gender gap in track choice.

${ }^{2}$ Cotton, McIntyre and Price (2013) show that the gender gap in competitive environments reduces in sequential contests: males outperform females in the first period contest, but in subsequent contests gender differences disappear. See also Price (2010) for a failed replication of the experiment of Niederle and Vesterlund (2007).
} 
University departments can fill new positions for associate or full professors choosing among the candidates who have obtained the national qualification. Promotions of successful insider candidates are possible and this is the choice followed in the vast majority of cases.

The framework of the Italian Qualification system allows us to investigate gender differences in the propensity to enter competitions aimed at reaching top positions in academia, neutralizing some factors typically associated to competitive settings and promotions: unobserved ex-ante abilities; different performance in the competition; differences in the willingness to change the type of tasks carried out or to change the workload; differences in the willingness to move to another university.

These characteristics differentiate our work from the recent paper by Bosquet, Combes and Garcia-Peñalosa (2014) analyzing gender gaps in the academic promotion system in the field of economics in France and finding a substantial lower probability in entering the competition for females. While in their context women could be discouraged from competing because of several oral presentations during the competition process and because of the necessity to move to a different university in case of success, in our framework these factors are neutralized since no presentation is due and since promotions typically occur in the same department. Furthermore, while Bosquet et al. (2014) focus only on the Economics field, thanks to the richness of our data we are able to investigate gender gaps in the propensity to enter competition considering all academic fields and to relate gender differences to field characteristics.

In order to investigate the probability of taking part to the evaluation procedure we have matched data on individuals effectively applying for promotion with data on potential applicants. We consider as potential applicants all the individuals holding a position in the Italian University system either as assistant professors ("ricercatori") - potential competitors for an associate professor position - or as associate professors - potential competitors for a full professor position.

Using these data we estimate the probability of applying for obtaining the qualification, controlling for some measures of scientific productivity, a number of individual characteristics and academic sub-fields fixed effects. We find that females have a lower probability of entering the competition of about 4 percentage points (p.p.). This holds true both for competitions to associate and full professor positions.

The female tendency to shy away from competition might be related to a number of different aspects: distaste for competitive settings, higher degree of risk aversion, propensity to underestimate their own ability, lower self-confidence (see Bertrand, 2011, for a summary).

We provide some interesting findings suggesting that self-confidence and risk aversion probably play a relevant role in explaining the lower propensity of women to compete. Since the ASN involves a penalty in case of failure (the exclusion from future competition for two years), individuals whose scientific productivity is not very high might avoid the risk and decide of not applying, especially those with low self-confidence. On the other hand, risk-aversion and self-confidence are less relevant for highly productive subjects. To focus on these aspects we have analyzed the gender 
gap in competitive attitudes in relation to individual scientific productivity. We find that gender gaps emerge only for individuals in the lower tail of the distribution of scientific productivity: females have a lower probability of entering the competition by about 7 percentage points with respect to similar males. In contrast, for individuals with higher levels of productivity we do not find any significant gender difference. Furthermore, females are especially likely to shy away from competition in fields in which the use of bibliometric indexes of productivity is less widespread. This might be due to the fact that in these fields the requirements to be met for being promoted are less clear, increasing the role played both by self-confidence and risk aversion in the decision to enter the competition.

The fear of women to be discriminated could also explain women's reluctance to apply. We find that, in fields in which females have been less successful in promotion in the recent past, there is a lower propensity for females to enter the process leading to promotions, while there are no differences in the propensity to apply in fields where females had good chances of promotions.

The paper is organized as follows. Section 2 describes the Italian academic promotion system. In Section 3 we present the data used in our analysis. In Section 4 we investigate whether females have a lower probability to take part in the National Scientific Qualification. Section 5 is devoted at investigating differences according to individual abilities. In Section 6 we carry out an analysis of the probability of entering the competition in relation to female perceived success in each sub-field. Section 7 concludes.

\section{The institutional background}

The rules governing careers in the Italian Universities have changed repeatedly over time. The system currently governing promotions to associate and full professor positions has been introduced in the Italian academic system in 2012, following a major reform of the University system in 2010 (the socalled "Gelmini Law", after the name of the former University Minister). The reform was aimed at increasing transparency and meritocracy through a centralized national competition called National Scientific Qualification. ${ }^{3}$ Academics aiming for promotion to associate or full professor positions are required to qualify in national competitions held at the sub-field level.

The Italian academia is organized in 14 different areas or fields (for example, "Physics", "Medicine", "Economics and Statistics"); within each field there are different sub-fields (for example, "Applied Physics", "Econometrics", "Private Law") for a total of 184 sub-fields. For each sub-field a committee of five members (four full Professors from Italian Universities and one foreign member from OECD countries) is randomly selected (among the full professors in each field who volunteered for the task and reached some scientific productivity standards).

\footnotetext{
${ }^{3}$ Previously, promotion were decided at the local level. Each university willing to fill a vacancy initiated a competition. The system is described in De Paola and Scoppa (2015).
} 
In this study we consider the procedure for obtaining the National Scientific Qualification launched in 2012 (the deadline for applications was the 20 $0^{\text {th }}$ November 2012 and evaluation procedures have been completed by the first semester of 2014). ${ }^{4}$

Committee members evaluate candidates to both associate and full professor positions and select those deserving the National Qualification. Committees had full autonomy on the criteria to be used in the evaluation but some criteria were suggested by the Ministry of Education, University and Research in relation to the research productivity of candidates in the previous ten years, as measured by some bibliometric indicators. In bibliometric fields (mainly scientific fields) ${ }^{5}$ candidates deserving qualification should have a score above the median (calculated among professors of the targeted position) in at least two of these three criteria: a) the number of articles published in scientific journals; b) the total number of citations; c) the h-index. In Social Sciences and in Humanities (nonbibliometric fields), successful candidates should pass the median in at least one of the following indicators: a) the number of articles published in scientific journals; b) the number of articles published in high quality journals ${ }^{6}$; c) the number of books.

There are no limits to the number of qualifications awarded in each field. Candidates who fail to obtain the qualification cannot participate in the ASN taking place in the following two years. ${ }^{7}$

University Departments can autonomously choose the full and associate professors to hire only among individuals who have obtained the ASN (insiders or outsiders). The effective hiring of successful candidates depends on the number of vacancies opened by the University Departments; currently, they have a limited amount of financial resources, especially to fill (the more costly) full professor positions.

The Italian system is similar to that currently in place in Spain and France. However, while in the French and Spanish systems candidates are evaluated both on their CVs and on the basis of one or several oral presentations (teaching lecture or seminar presentation of own research), in the Italian ASN, evaluation committees assess candidates exclusively on the basis of their publications and CVs. The process does not involve any direct interaction between committees' members and candidates. Therefore, the role played by unobserved abilities in teaching and in presenting research is unlikely to affect our results. Even if, as shown by Gneezy, Niederle and Rustichini (2003) and Gneezy and Rustichini (2004), females perform worse than males in competitive settings, in our context this should have no impact on the decision to apply.

In addition, Italian academics have similar obligations and constraints at all the hierarchical levels, carry out similar tasks and promotions do not imply longer working hours. This implies that

\footnotetext{
${ }^{4}$ The call for eligible evaluators was published in June 2012. After the deadline for candidates' application, the five members of each evaluation committee were randomly selected.

${ }^{5}$ Bibliometric fields include Mathematics, Physics, Chemistry, Earth Sciences, Biology, Medicine, Agricultural and Veterinary Sciences, Civil Engineering and Architecture, Industrial and Information Engineering, Psychology.

${ }^{6}$ The list of high quality journals in each field has been determined by an evaluation agency with the help of several scientific committees.

${ }^{7}$ For a detailed analysis of the Italian ASN see Bagues, Sylos-Labini and Zinovyeva (2014). 
gender differences in taking part into the competition can hardly be explained considering constraints deriving from family care and domestic responsibility.

Finally, since taking part in the ASN represents only a first step to obtain a full or associate professor position, the role played by mobility preferences should be very limited. The decision to move to a different city will be required only if, once obtained the National Qualification, a University different from the one currently employing the candidate will offer him/her a position; given the low mobility characterizing the Italian University system, this possibility is rare: typically individuals obtaining the ASN are promoted by the same University currently employing them. Therefore, also females characterized by low mobility (for family reasons) should have no problems in taking part to this competition.

\section{The data}

For our analysis we use data from different sources. From the website of the Italian Ministry of Education, University and Research we have collected the lists of all individuals holding a position in the Italian University system either as associate professors (16,137 potential candidates for full professor positions) or as assistant professors (26,723 potential candidates for associate professor positions) ${ }^{8}$

We have used the same source to obtain information on gender (inferred from the candidate's first name), the affiliation of potential candidates and of eligible and effective committee members, whether candidates have tenure and their years of experience (since the year 2000).

From the National Scientific Qualification's webpage we have collected data on the list of effective candidates and on the evaluation procedures. ${ }^{9}$ Then, for each sub-field we matched the list of applicants to the list of potential candidates. Using these data we have built a dummy variable, Application, equal to one when a potential candidate has applied for a position (and zero otherwise).

In doing this, we disregard candidates who have applied for a position in a sub-field that is different from their current sub-field (about 9\% of candidates applied for other sub-fields) and we do not consider applications to a full professor position made by assistant professors. ${ }^{10}$ Furthermore, we do not consider all the external candidates applying for a qualification, that is, those who are not currently assistant or associate professors in Italian Universities, since for this category we are not able to define the population of potential candidates.

Some indicators of candidates' scientific productivity are available from the ASN website. Unfortunately, we are not able to use this information in our analysis, since the same detailed

\footnotetext{
${ }^{8}$ See the website: http://cercauniversita.cineca.it/php5/docenti/cerca.php

${ }^{9}$ See the website: http://abilitazione.miur.it/public/pubblicacandidati.php

${ }^{10}$ Our results remain substantially unchanged when we include candidates applying for a position in a sub-field that is different from their current one or when we consider assistant professors applying for qualification for full professor.
} 
information is not available for potential candidates who decided to not take part in the qualification procedure. Then, in order to gather information on the scientific productivity of potential candidates working in the Italian University system we have decided to use the "Publish or Perish" software based on Google Scholar. Due to the huge amount of work related to data collection, we have chosen to draw a stratified random sample of $20 \%$ of the whole population (using as strata the subfields, positions, gender, decision to apply) ending up with a sample of 8,523 observations.

For each individual in this restricted sample we have collected data on the number of publications, citations, $h$-index and $g$-index. ${ }^{11}$ Using these data we have undertaken a principal component analysis to obtain a comprehensive measure of individual scientific productivity (only the first component was considered), which we call Productivity.

Using the affiliations of both evaluators and potential candidates we build an indicator of professional networks between potential candidates and potential committee members, Potential Connections, taking the value of one when at least one professor in the set of eligible evaluators works (or has worked in the past) in the same university in which the potential candidate is employed, and zero otherwise. Similarly, we proceed considering the effective committee members and build a dummy variable, Connections, taking the value of one when at least one of the committee members works (or has worked in the past) in the same university employing the potential candidate and zero otherwise. Moreover, using the geographical location of the University in which each individual is affiliated we build 5 geographical dummies (North-West, North-East, Centre, South, Islands).

We have also some information on candidates' seniority in the academia. In the Italian system, professors hired at any level have to spend an initial period of 3 years ("No Tenure") after which they are hired permanently (conditional on satisfactory performance). Although almost everyone obtains tenure, the indicator variable "No tenure" is useful as a measure of seniority. Furthermore, since we observe for each candidate when he/she was hired by an Italian university (starting from the year 2000), we use this information to build the variable Experience, that is, the number of years since the individual has been hired. ${ }^{12}$

Descriptive statistics for both the full sample of potential candidates (Panel a) and potential candidates included in our restricted sample (Panel b) are reported in Table 1. In the appendix of this paper we report separate descriptive statistics for potential candidates to associate (Table A) and full professor positions (Table B).

\footnotetext{
${ }^{11}$ The $h$-index (Hirsch index) is based on the distribution of citations received by a given researcher's publications. A scientist has index $\mathrm{h}$ if $\mathrm{h}$ of his/her $\mathrm{N}$ papers have at least $\mathrm{h}$ citations each, and the other $(\mathrm{N}-\mathrm{h})$ papers have no more than $\mathrm{h}$ citations each. Given a set of articles ranked in decreasing order of the number of citations that they received, the $g$-index is the (unique) largest number such that the top $g$ articles received (together) at least $\mathrm{g}^{\wedge} 2$ citations.

${ }^{12}$ We impute 5 more years of experience to assistant professors who in the year 2000 were already tenured and impute 10 more years of experience to associate professors who in the year 2000 were already tenured.
} 


\section{Panel (a). Whole sample}

\begin{tabular}{lccccc} 
& Mean & St. Dev. & Min & Max & Obs. \\
\hline Application & 0.516 & 0.500 & 0 & 1 & 42860 \\
Female & 0.411 & 0.492 & 0 & 1 & 42860 \\
Ass. Prof. Competition & 0.623 & 0.485 & 0 & 1 & 42860 \\
North-West & 0.235 & 0.424 & 0 & 1 & 42860 \\
North-East & 0.189 & 0.392 & 0 & 1 & 42860 \\
Centre & 0.283 & 0.451 & 0 & 1 & 42860 \\
South & 0.181 & 0.385 & 0 & 1 & 42860 \\
Islands & 0.112 & 0.315 & 0 & 1 & 42860 \\
No tenure & 0.179 & 0.383 & 0 & 1 & 42860 \\
Potential Connections & 0.637 & 0.481 & 0 & 1 & 42860 \\
Effective Connections & 0.179 & 0.383 & 0 & 1 & 42860 \\
Experience & 10.388 & 6.244 & 0 & 22 & 42860 \\
Bibliometric Fields & 0.630 & 0.483 & 0 & 1.320 & 42860 \\
Females' Career Success & 0.482 & 0.197 & & & 42860 \\
\hline
\end{tabular}

Panel (b). Our sample with productivity variables

\begin{tabular}{|c|c|c|c|c|c|}
\hline & Mean & St. Dev. & Min & $\operatorname{Max}$ & Obs. \\
\hline Application & 0.518 & 0.500 & 0 & 1 & 8523 \\
\hline Female & 0.409 & 0.492 & 0 & 1 & 8523 \\
\hline Ass. Prof. Competition & 0.625 & 0.484 & 0 & 1 & 8523 \\
\hline North-West & 0.237 & 0.425 & 0 & 1 & 8523 \\
\hline North-East & 0.186 & 0.389 & 0 & 1 & 8523 \\
\hline Centre & 0.285 & 0.451 & 0 & 1 & 8523 \\
\hline South & 0.180 & 0.384 & 0 & 1 & 8523 \\
\hline Islands & 0.113 & 0.316 & 0 & 1 & 8523 \\
\hline No tenure & 0.182 & 0.386 & 0 & 1 & 8523 \\
\hline Potential Connections & 0.641 & 0.480 & 0 & 1 & 8523 \\
\hline Effective Connections & 0.176 & 0.381 & 0 & 1 & 8523 \\
\hline Experience & 10.358 & 6.275 & 0 & 22 & 8523 \\
\hline Bibliometric Fields & 0.627 & 0.483 & 0 & 1 & 8523 \\
\hline Papers & 33.932 & 36.351 & 0 & 202 & 8523 \\
\hline Citations & 443.616 & 823.484 & 0 & 4965 & 8523 \\
\hline h-index & 7.661 & 7.414 & 0 & 35 & 8523 \\
\hline g-index & 13.693 & 13.843 & 0 & 66 & 8523 \\
\hline Females' Career Success & 0.482 & 0.197 & 0 & 1.320 & 8523 \\
\hline
\end{tabular}

Notes: Data on current assistant and associate professors are from the website of the Ministry of Education, University and Research. Data on applications for the National Qualification are from the ASN's website. "Publish or Perish" software based on Google Scholar is used to gather data on Scientific Productivity.

The descriptive statistics of the full and the restricted sample are almost identical, implying that our restricted sample is a satisfactory representation of the whole universe. The percentage of female potential candidates is about $41 \%$, higher in competitions to associate professor (44\%) than in competitions to full professor (34\%). About $52 \%$ of potential candidates have applied for promotion (53\% and 50\%, respectively, for associate and full professor positions). About $42 \%$ of individuals are from Northern Universities, 28\% are from the Centre and 30\% are from the South and Islands. About $18 \%$ has no tenure (less than 3 years in their current position). About $64 \%$ of potential candidates have connections with at least one of the eligible evaluators, while $18 \%$ of them have effective connections with one member of the committee.

On average, potential candidates have 10 years of tenure, for potential candidates to associate professor positions tenure is shorter (about 7.7 years) than for candidates to full professor positions 
(about 15 years). As shown in Panel (b), candidates have published on average 34 papers, receiving 443 total citations, have a $h$-index of 7 and a $g$-index of 13.

\section{Gender differences in the probability of taking part in the competition}

To investigate whether females are less likely than males to take part in the competition process governing academic promotions in Italy, we estimate the following Probit model:

$$
\operatorname{Pr}\left(\text { Application }_{i j}=1 \mid X\right)=\Phi\left(\beta_{0}+\beta_{1} \text { Female }_{i}+\beta_{2} \text { Productivity }_{i}+\beta_{3} W_{i}+\lambda_{j}+\mu_{j}\right)
$$

where $i$ is an index for each individual and $j$ is an index for sub-fields. The dependent variable Application $_{i j}$ is a dummy variable equal to one for a potential candidate who effectively applied for the relevant position at the National Qualification in sub-field $j$ and it is equal to zero for a potential candidate who did not apply.

We model the probability of application for the competition as a function of the candidate's gender, using the dummy Female $_{i}$, the candidate's scientific productivity, a vector $W_{i}$ of individual characteristics (including years of experience, potential and effective connections, dummies for the geographical location of the University in which the individual currently works); $\lambda_{j}$ are 184 dummies for sub-fields and $\mu_{j}$ represents the type of academic position (full or associate professor).

The effect of our interest is the impact of Female: ceteris paribus (in particular taking as constant individual productivity) the marginal effect of Female shows whether females have a different probability, compared to males, to apply for obtaining a qualification for associate or full professor. More in general, provided that we have good measures of individual productivity and we take into account other possible determinants of the propensity to apply for the qualification, the effect of Female represents gender differences in the probability of taking part in the competition.

Equation [1] is estimated using a Probit model and the corresponding marginal effects are reported in Table 2. In all the estimates, standard errors are corrected for heteroskedasticity and allowed for clustering at sub-field level. In the first specification we estimate the difference in the probability of application between males and females on the universe of potential candidates $(42,860$ observations) controlling only for the type of academic position (notice that we do not have information on scientific productivity for the full sample). Estimates show that a female has a lower probability of applying for promotion of 5.2 percentage points $(t$-stat=-6.9). In column (2) we include all the available controls for individual characteristics for the full sample of potential candidates and 184 sub-field dummies. After controlling for Experience, Experience Squared, No Tenure, for both Potential and Effective Connections, and for 5 dummies of geographical areas, we find that women have a lower probability of enter the competition of 6.7 percentage points. Similar estimates emerge in 
column (3) where we also include dummies for Universities (93) instead of dummies for geographical areas.

As regards controls, we find that potential candidates without tenure have a lower probability of applying (14 percentage points less), while the probability of application is concave with respect to the years of experience (initially increasing and then decreasing after about 10 years). Individuals with colleagues in the list of eligible evaluators (Potential Connections) are about 6 percentage points more likely to apply. Academics from South or Islands are less likely to apply (not reported).

To further check that the restricted sample for which we collected data on individual scientific productivity is a representative sample of the universe of potential candidates, in columns (4), (5) and (6) of Table 2 we replicate on the restricted sample the same specifications reported in the first three columns. The results are very similar to those obtained for the whole sample of potential candidates. Once we control for the full set of individual characteristics and for sub-field and university dummies (in column 6) we find that in the restricted sample females have a lower probability of entering the competition of 7.7 percentage points $(t$-stat=-8.9).

We obtain similar findings estimating separately for competitions for associate and full professor positions (not reported).

Table 2. Probit estimates of the probability of entering the competition

\begin{tabular}{|c|c|c|c|c|c|c|}
\hline & (1) & (2) & (3) & (4) & (5) & (6) \\
\hline & Full sample & Full sample & Full sample & $\begin{array}{c}\text { Restricted } \\
\text { Sample }\end{array}$ & $\begin{array}{c}\text { Restricted } \\
\text { Sample }\end{array}$ & $\begin{array}{c}\text { Restricted } \\
\text { Sample }\end{array}$ \\
\hline Female & $\begin{array}{c}-0.052 * * * \\
(0.008)\end{array}$ & $\begin{array}{c}-0.067 * * * \\
(0.007)\end{array}$ & $\begin{array}{c}-0.066 * * * \\
(0.007)\end{array}$ & $\begin{array}{c}-0.055^{*} * * \\
(0.008)\end{array}$ & $\begin{array}{c}-0.077 * * * \\
(0.008)\end{array}$ & $\begin{array}{c}-0.077 * * * \\
(0.009)\end{array}$ \\
\hline Associate Prof. Comp. & $\begin{array}{c}0.031 * * * \\
(0.008)\end{array}$ & $\begin{array}{c}-0.076^{* * *} \\
(0.009)\end{array}$ & $\begin{array}{c}-0.075 * * * \\
(0.009)\end{array}$ & $\begin{array}{c}0.028 * * * \\
(0.008)\end{array}$ & $\begin{array}{c}-0.072 * * * \\
(0.013)\end{array}$ & $\begin{array}{c}-0.073 * * * \\
(0.013)\end{array}$ \\
\hline No tenure & & $\begin{array}{c}-0.137 * * * \\
(0.011)\end{array}$ & $\begin{array}{c}-0.141 * * * \\
(0.011)\end{array}$ & & $\begin{array}{c}-0.117 * * * \\
(0.021)\end{array}$ & $\begin{array}{c}-0.116^{* * * *} \\
(0.022)\end{array}$ \\
\hline Potential Connections & & $\begin{array}{c}0.059 * * * \\
(0.007)\end{array}$ & $\begin{array}{c}0.056 * * * \\
(0.008)\end{array}$ & & $\begin{array}{c}0.069 * * * \\
(0.014)\end{array}$ & $\begin{array}{c}0.071 * * * \\
(0.015)\end{array}$ \\
\hline Effective Connections & & $\begin{array}{l}-0.006 \\
(0.009)\end{array}$ & $\begin{array}{l}-0.003 \\
(0.009)\end{array}$ & & $\begin{array}{l}-0.013 \\
(0.016)\end{array}$ & $\begin{array}{l}-0.004 \\
(0.016)\end{array}$ \\
\hline Experience & & $\begin{array}{c}0.021 * * * \\
(0.002)\end{array}$ & $\begin{array}{c}0.021 * * * \\
(0.002)\end{array}$ & & $\begin{array}{c}0.030 * * * \\
(0.005)\end{array}$ & $\begin{array}{c}0.030 * * * \\
(0.005)\end{array}$ \\
\hline Experience Sq. & & $\begin{array}{c}-0.002 * * * \\
(0.000)\end{array}$ & $\begin{array}{c}-0.002 * * * \\
(0.000)\end{array}$ & & $\begin{array}{c}-0.002 * * * \\
(0.000)\end{array}$ & $\begin{array}{c}-0.002 * * * \\
(0.000)\end{array}$ \\
\hline Geographical dummies (5) & $\mathrm{NO}$ & YES & $\mathrm{NO}$ & $\mathrm{NO}$ & YES & $\mathrm{NO}$ \\
\hline Sub-field dummies (184) & $\mathrm{NO}$ & YES & YES & NO & YES & YES \\
\hline University dummies (93) & NO & NO & YES & NO & NO & YES \\
\hline Observations & 42860 & 42860 & 42860 & 8523 & 8523 & 8523 \\
\hline Pseudo R-squared & 0.002 & 0.079 & 0.084 & 0.002 & 0.083 & 0.093 \\
\hline
\end{tabular}

Notes: The Table reports marginal effects of Probit estimates (evaluated at the mean values of the explanatory variables in the sample). The dependent variable is Application. Standard errors (corrected for heteroskedasticity and allowed for clustering at subfield level) are reported in parentheses. The symbols $* * *, * * *$ indicate that coefficients are statistically significant, respectively, at the 1,5 , and 10 percent level. 
In Table 3, in order to avoid any bias that may derive from the fact that candidate's gender may be related to individual productivity, we include among regressors the comprehensive measure of scientific productivity, Productivity. ${ }^{13}$

In the first three columns of Table 3 we report the same specifications of Table 2 simply adding Productivity. Estimates show that even after controlling for productivity, females are less likely than males to take part in the competition. However, the magnitude of the coefficient on Female turns out to be smaller with respect to Table 2 , as a consequence of the fact that productivity is typically lower for females. Once we control for the full set of individual characteristics and dummies for subfields and for universities (column 3) we find that a female has a lower probability of entering the competition of 4.3 percentage points $(t$-stat=-4.9). Given that the probability of applying for qualification is about $52 \%$ in our sample, this amounts to a lower probability of competing of about $8 \%$ for females.

Table 3. Probit estimates of the probability of competing controlling for productivity

\begin{tabular}{|c|c|c|c|c|c|c|}
\hline & $\begin{array}{c}(1) \\
\text { Whole }\end{array}$ & $\begin{array}{c}(2) \\
\text { Whole }\end{array}$ & $\begin{array}{c}(3) \\
\text { Whole }\end{array}$ & $\begin{array}{c}(4) \\
\text { Whole }\end{array}$ & $\begin{array}{c}(5) \\
\text { Ass. Prof. } \\
\text { Competition }\end{array}$ & $\begin{array}{c}(6) \\
\text { Full Prof. } \\
\text { Competition }\end{array}$ \\
\hline Female & $\begin{array}{c}-0.043 * * * \\
(0.009)\end{array}$ & $\begin{array}{c}-0.044 * * * \\
(0.009)\end{array}$ & $\begin{array}{c}-0.043 * * * \\
(0.009)\end{array}$ & $\begin{array}{c}-0.047 * * * \\
(0.012)\end{array}$ & $\begin{array}{c}-0.043 * * * \\
(0.010)\end{array}$ & $\begin{array}{c}-0.058 * * * \\
(0.015)\end{array}$ \\
\hline Productivity & $\begin{array}{c}0.105^{* * *} * \\
(0.007)\end{array}$ & $\begin{array}{c}0.120 * * * \\
(0.008)\end{array}$ & $\begin{array}{c}0.121 * * * \\
(0.008)\end{array}$ & $\begin{array}{c}0.124 * * * \\
(0.011)\end{array}$ & $\begin{array}{c}0.129 * * * \\
(0.013)\end{array}$ & $\begin{array}{c}0.122 * * * \\
(0.011)\end{array}$ \\
\hline Associate Prof. Comp. & $\begin{array}{c}0.099 * * * \\
(0.010)\end{array}$ & $\begin{array}{c}0.021 \\
(0.015)\end{array}$ & $\begin{array}{c}0.021 \\
(0.015)\end{array}$ & $\begin{array}{c}0.103 * * * \\
(0.021)\end{array}$ & & \\
\hline No tenure & & $\begin{array}{c}-0.128 * * * \\
(0.021)\end{array}$ & $\begin{array}{c}-0.126^{* * *} * \\
(0.022)\end{array}$ & $\begin{array}{c}-0.094 * * * \\
(0.028)\end{array}$ & $\begin{array}{c}-0.146 * * * \\
(0.033)\end{array}$ & $\begin{array}{l}-0.000 \\
(0.033)\end{array}$ \\
\hline Potential Connections & & $\begin{array}{c}0.047 * * * \\
(0.014)\end{array}$ & $\begin{array}{c}0.051 * * * \\
(0.015)\end{array}$ & $\begin{array}{c}0.065^{* * * *} \\
(0.018)\end{array}$ & $\begin{array}{c}0.042 * * \\
(0.018)\end{array}$ & $\begin{array}{c}0.055^{* *} * \\
(0.025)\end{array}$ \\
\hline Effective Connections & & $\begin{array}{l}-0.020 \\
(0.016)\end{array}$ & $\begin{array}{l}-0.015 \\
(0.016)\end{array}$ & $\begin{array}{c}0.016 \\
(0.020)\end{array}$ & $\begin{array}{l}-0.015 \\
(0.021)\end{array}$ & $\begin{array}{l}-0.027 \\
(0.032)\end{array}$ \\
\hline Experience & & $\begin{array}{c}0.027 * * * \\
(0.005)\end{array}$ & $\begin{array}{c}0.028 * * * \\
(0.005)\end{array}$ & $\begin{array}{c}0.066^{* * * *} \\
(0.013)\end{array}$ & $\begin{array}{c}0.046 * * * \\
(0.009)\end{array}$ & $\begin{array}{c}0.049 * * * \\
(0.011)\end{array}$ \\
\hline Experience Sq. & & $\begin{array}{c}-0.002 * * * \\
(0.000) \\
\end{array}$ & $\begin{array}{c}-0.002 * * * \\
(0.000) \\
\end{array}$ & $\begin{array}{c}-0.004 * * * \\
(0.001) \\
\end{array}$ & $\begin{array}{c}-0.003 * * * \\
(0.000) \\
\end{array}$ & $\begin{array}{c}-0.002 * * * \\
(0.000) \\
\end{array}$ \\
\hline Scientific Area dummies (14) & YES & $\mathrm{NO}$ & $\mathrm{NO}$ & $\mathrm{NO}$ & $\mathrm{NO}$ & $\mathrm{NO}$ \\
\hline Geographical dummies (5) & NO & YES & NO & NO & YES & YES \\
\hline Subfield dummies (184) & NO & YES & YES & YES & YES & YES \\
\hline University dummies (93) & NO & NO & YES & YES & NO & NO \\
\hline Observations & 8523 & 8523 & 8511 & 5324 & 5331 & 3183 \\
\hline Pseudo R-squared & 0.085 & 0.150 & 0.159 & 0.177 & 0.160 & 0.173 \\
\hline
\end{tabular}

Notes: The Table reports marginal effects of Probit estimates (evaluated at the mean values of the explanatory variables in the sample). The dependent variable is Application. Standard errors (corrected for heteroskedasticity and allowed for clustering at subfield level) are reported in parentheses. The symbols $* * *, * *, *$ indicate that coefficients are statistically significant, respectively, at the 1,5 , and 10 percent level.

Since in our data individual experience is censored (we do not observe the year of hiring if an individual has been hired before 2000) and years of experience could differ between males and females, to avoid possible biases we estimate the specification reported in column (3) only for the sample of individuals hired after the year 2000 (5324 observations). Results, reported in column (4),

\footnotetext{
${ }^{13}$ In a preliminary regression we notice that, controlling for individual characteristics, sub-field dummies and type of academic position, females on average turn out to have a lower scientific productivity than males (coefficient on Female is $-0.312 ; t$-stat=-9.54) (results not reported).
} 
are very similar to those shown in column (3): females have a lower probability of applying of 4.7 percentage points.

In columns (5) and (6) we re-estimate specification (3), separately for competitions to associate and full professor positions. We find that females are especially reluctant to take part to the competition for full professor qualification (5.8 percentage points less than males instead of 4.3 for associate professor competition). However, by estimating the regression on the whole sample using an interaction term between Female and Associate Prof. Comp we find that the gender difference between positions is not statistically significant.

As expected, the candidate's scientific productivity strongly contributes to the probability of entering the competition: an increase of one standard deviation in Productivity ( $\mathrm{SD}=1.85$ ) leads to an increase in the probability of taking part in the competition of about 22.4 percentage points with a $t$ stat of 15.1 (column 3). Potential Connections play a relevant role in explaining the probability of applying for qualification (5 percentage points more), while Effective Connections do not produce any effect: this is probably due to the fact that while professors in the eligible list were known before the deadline for application, effective committee members were selected and announced only after the deadline. ${ }^{14}$ The number of years of experience has a non-linear relationship: at the beginning the probability of application increases with the years of experience but declines after a maximum of 7.4 years. $^{15}$

As a robustness check we have also estimated all previous specifications with a Linear Probability Model obtaining almost identical results.

All in all, we find a significant difference between men and women in the propensity to enter in competition. However, this difference is not high, much lower than the differences of about $25-30 \%$ found by Bosquet et al. (2014) or by Niederle and Vesterlund (2007).

\section{Self-confidence, risk-aversion and attitudes toward competition}

The tendency of females to shy away from competition might be related to gender differences in taste for competition, or to differences in other psychological traits typically influencing entry into competition, such as the tendency of females to underestimate their own abilities and to be more riskaverse than men. ${ }^{16}$

\footnotetext{
${ }^{14}$ Once known the effective members of the evaluation committee, candidates have only the possibility to withdraw from the competition. Unfortunately, the information on withdrawals is not publicly available.

${ }^{15} \mathrm{We}$ also find that in scientific fields potential candidates are much less likely to apply (20 percentage points less), probably because in these fields reaching the bibliometric thresholds suggested by the Ministry for promotion was more demanding. Individuals from Northern Universities are more likely to apply (3-4 percentage points more) with respect to the Centre-South, whereas those from Islands are much less likely to apply (about 10 percentage points less) (estimates not reported).

${ }^{16}$ In some recent laboratory experiments, researchers have tried to understand the role played in determining competitiveness by such differences in psychological traits undertaking a number of strategies aimed at neutralizing their effects. For example, some papers try to measure beliefs and risk-aversion of participants and use them as control variables in the regressions. Other works neutralize risk-aversion by offering to participants,
} 
Differences in risk-aversion and in self-confidence are likely to be especially relevant for the decisions taken by individuals whose scientific productivity is not particularly high and that could not meet all the requirements needed for promotion. ${ }^{17}$ Individuals characterized by a relatively low scientific productivity have a higher probability of failure and then a higher probability of incurring in the penalty that excludes them from the ASN's competitions that will be held in the following two years.

To focus on this aspect we have analyzed the gender gap in competitiveness in relation to the individual scientific productivity using our variable Productivity. We split our sample considering separately, for each sub-fields and tier (associate and full professor competition), potential candidates belonging to the first quartile (below the $25^{\text {th }}$ percentile), potential candidates in the second and third quartile and potential candidates in the fourth quartile (above the $75^{\text {th }}$ percentile).

Results are reported in Table 4. We find that the gender gap in the probability of entering the competition varies according to the productivity level. The gender gap is particularly striking for individuals below the $25^{\text {th }}$ percentile of the scientific productivity distribution (column 1): among this sample of individuals, females show a lower probability of entering the competition of about 6.8 percentage points This is a quite large effect: given that the probability of applying for qualification for "low productivity" individuals is about $28 \%$, it translates in a lower probability of applying of about $24 \%$ for "low productivity" females with respect to their male counterparts.

On the other hand, the gender gap reduces considerable (to 3.9 p.p.) in column (2) for individuals with average productivity (collocated in the second and third quartile in each sub-field) and vanishes completely for individuals with a high level of scientific productivity (column 3). Then, in contrast to Niederle and Vesterlund (2007) that find that even high ability women tend to shy away from competition, we find that high ability women are not scared by competitive settings.

In column (4) we consider the full sample and include an interaction term between Productivity (demeaned) and Female. We find that the interaction variable is positive and statistically significant: a woman with average productivity has a lower probability of entering the competition of about 3.8 percentage points, but this difference shrinks to zero for individuals with higher productivity (one SD higher than the mean), whereas rises to about 8.4 percentage points for individuals with lower productivity (one SD lower than the mean).

In columns (5) and (6) we estimate separately for Associate and Full professor competition, finding similar results: women with low productivity are less likely to apply than comparable men, whereas women and men with high productivity are equally likely to apply.

in alternative to tournaments, choices with the same degree of risk. In the same vein, subjects' beliefs are manipulated by changing the task performed by participants or providing them information on their relative performance. See the review of Niederle and Vesterlund (2011) for references and discussion of these aspects.

${ }^{17}$ It is common wisdom that women tend to apply for a promotion only when they meet all the requirements, while men apply also when they are far from reaching the threshold (Sandberg, 2013). 
Table 4. Heterogeneous effects according to scientific productivity. Probit estimates of the probability of entering the competition

\begin{tabular}{|c|c|c|c|c|c|c|}
\hline & $\begin{array}{c}\text { (1) } \\
\text { I quartile }\end{array}$ & $\begin{array}{c}\text { (2) } \\
\text { II and III } \\
\text { quartiles }\end{array}$ & $\begin{array}{c}\text { (3) } \\
\text { IV quartile }\end{array}$ & $\begin{array}{c}\text { (4) } \\
\text { Whole }\end{array}$ & $\begin{array}{c}\text { (5) } \\
\text { Ass. Prof. } \\
\text { Competition }\end{array}$ & $\begin{array}{c}(6) \\
\text { Full Prof. } \\
\text { Competition }\end{array}$ \\
\hline Female & $\begin{array}{c}-0.068 * * * \\
(0.025)\end{array}$ & $\begin{array}{c}-0.039 * * \\
(0.016)\end{array}$ & $\begin{array}{l}-0.013 \\
(0.021)\end{array}$ & $\begin{array}{c}-0.038 * * * \\
(0.009)\end{array}$ & $\begin{array}{c}-0.027 * * \\
(0.013)\end{array}$ & $\begin{array}{c}-0.059 * * * \\
(0.015)\end{array}$ \\
\hline Productivity & $\begin{array}{c}0.058 \\
(0.039)\end{array}$ & $\begin{array}{c}0.222 * * * \\
(0.022)\end{array}$ & $\begin{array}{l}-0.006 \\
(0.008)\end{array}$ & $\begin{array}{c}0.113 * * * \\
(0.008)\end{array}$ & $\begin{array}{c}0.117 * * * \\
(0.014)\end{array}$ & $\begin{array}{c}0.119 * * * \\
(0.011)\end{array}$ \\
\hline Ass. Prof. Comp. & $\begin{array}{c}-0.067 * * \\
(0.033)\end{array}$ & $\begin{array}{c}0.135 * * * \\
(0.026)\end{array}$ & $\begin{array}{l}-0.044 * \\
(0.025)\end{array}$ & $\begin{array}{c}0.022 \\
(0.015)\end{array}$ & & \\
\hline No tenure & $\begin{array}{c}-0.131 * * * \\
(0.032)\end{array}$ & $\begin{array}{c}-0.117 * * * \\
(0.033)\end{array}$ & $\begin{array}{c}-0.087 * * \\
(0.038)\end{array}$ & $\begin{array}{c}-0.130 * * * \\
(0.021)\end{array}$ & $\begin{array}{c}-0.148 * * * \\
(0.033)\end{array}$ & $\begin{array}{c}-0.001 \\
(0.033)\end{array}$ \\
\hline Potential Connections & $\begin{array}{l}0.046^{*} \\
(0.027)\end{array}$ & $\begin{array}{c}0.024 \\
(0.019)\end{array}$ & $\begin{array}{c}0.024 \\
(0.027)\end{array}$ & $\begin{array}{c}0.046 * * * \\
(0.014)\end{array}$ & $\begin{array}{c}0.042 * * \\
(0.018)\end{array}$ & $\begin{array}{c}0.055 * * \\
(0.025)\end{array}$ \\
\hline Effective Connections & $\begin{array}{c}0.009 \\
(0.034)\end{array}$ & $\begin{array}{c}-0.045^{*} \\
(0.025)\end{array}$ & $\begin{array}{c}0.011 \\
(0.028)\end{array}$ & $\begin{array}{l}-0.019 \\
(0.016)\end{array}$ & $\begin{array}{l}-0.012 \\
(0.021)\end{array}$ & $\begin{array}{l}-0.027 \\
(0.032)\end{array}$ \\
\hline Experience & $\begin{array}{l}0.017 * \\
(0.009)\end{array}$ & $\begin{array}{c}0.032 * * * \\
(0.006)\end{array}$ & $\begin{array}{c}0.020 * * * \\
(0.007)\end{array}$ & $\begin{array}{c}0.027 * * * \\
(0.005)\end{array}$ & $\begin{array}{c}0.045^{* * * *} \\
(0.009)\end{array}$ & $\begin{array}{c}0.049 * * * \\
(0.011)\end{array}$ \\
\hline Experience Sq. & $\begin{array}{c}-0.001 * * * \\
(0.000)\end{array}$ & $\begin{array}{c}-0.002 * * * \\
(0.000)\end{array}$ & $\begin{array}{c}-0.001 * * * \\
(0.000)\end{array}$ & $\begin{array}{c}-0.002 * * * \\
(0.000)\end{array}$ & $\begin{array}{c}-0.003 * * * \\
(0.000)\end{array}$ & $\begin{array}{c}-0.002 * * * \\
(0.000)\end{array}$ \\
\hline Female*Productivity & & & & $\begin{array}{c}0.026 * * \\
(0.011)\end{array}$ & $\begin{array}{c}0.038 * * \\
(0.016)\end{array}$ & $\begin{array}{c}0.010 \\
(0.013)\end{array}$ \\
\hline $\begin{array}{l}\text { Observations } \\
\text { Pseudo R-squared }\end{array}$ & $\begin{array}{l}2071 \\
0.158\end{array}$ & $\begin{array}{l}4095 \\
0.139\end{array}$ & $\begin{array}{l}2076 \\
0.119\end{array}$ & $\begin{array}{l}8523 \\
0.151\end{array}$ & $\begin{array}{l}5331 \\
0.162\end{array}$ & $\begin{array}{l}3183 \\
0.173\end{array}$ \\
\hline
\end{tabular}

Notes: The Table reports marginal effects of Probit estimates (evaluated at the mean values of the explanatory variables in the sample). The dependent variable is Application. In all specifications we control for individual characteristics and sub-field dummies (not reported) as in specification 3 of Table 3. Standard errors (corrected for heteroskedasticity and allowed for clustering at subfield level) are reported in parentheses. The symbols $* * *, * *$, * indicate that coefficients are statistically significant, respectively, at the 1,5 , and 10 percent level.

In Figure 1 we plot the predicted probability of application of men (the blue solid line) and women (the red dashed line) in relation to their scientific productivity based on the results of column 4 of Table 4 (the grey areas represent 95\% confidence intervals). The vertical distance between the two lines represents the gender difference in the probability of competing. As shown in the Figure, this gap tends to close when productivity increases: the two lines representing male's and female's probability of application become indistinguishable once standardized productivity reaches a value of about 1 . Therefore, high productivity women tend to compete as equally as men, while women with lower productivity tend to shy away from competition with respect to similarly productive men, probably because of females' higher risk-aversion and lower self-confidence. 


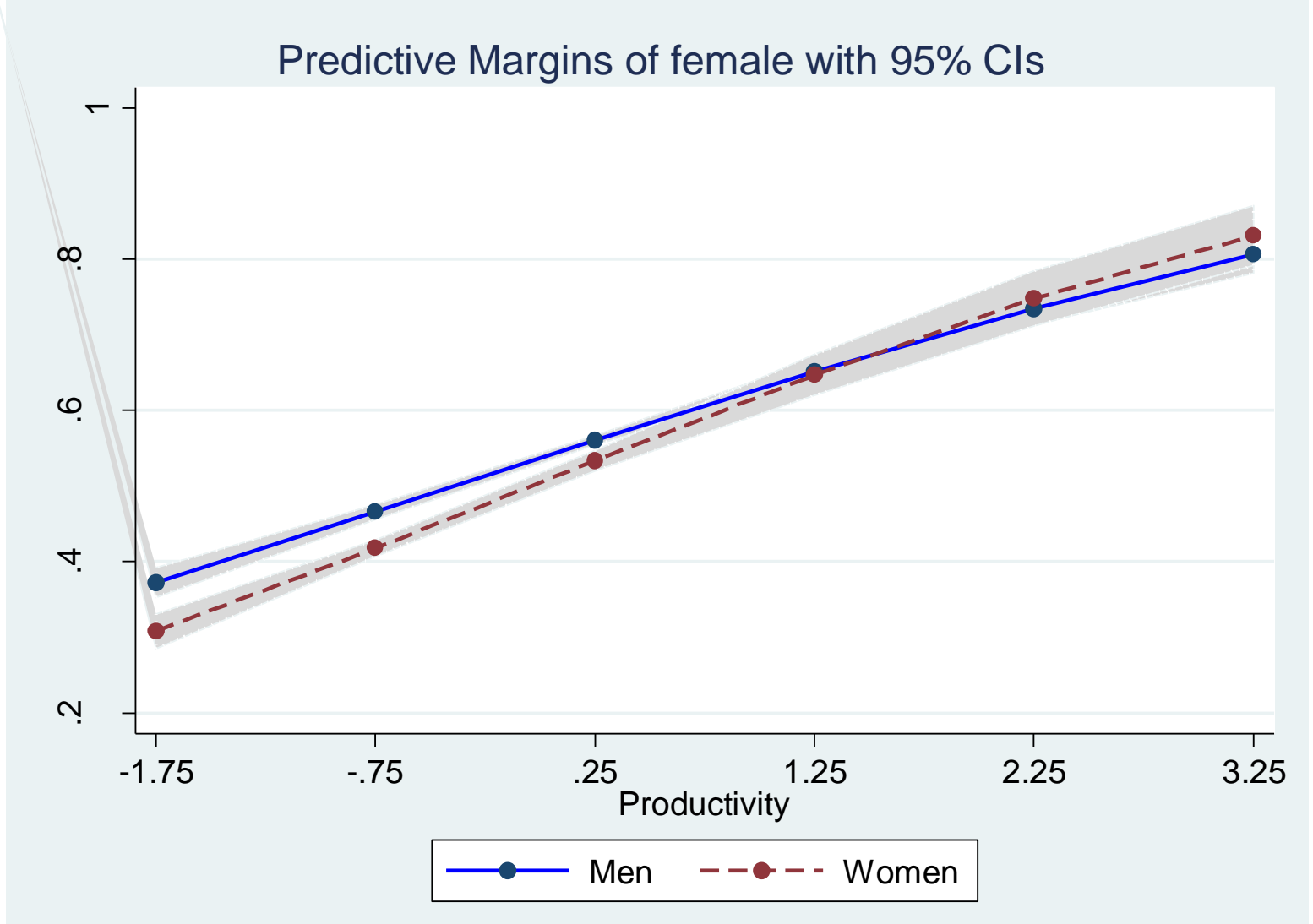

Figure 1. Probability of competing for men and women in relation to scientific productivity

A possibility that is worthwhile to investigate is whether females are more reluctant to enter the competition when the requirements for being promoted are less clear. In fact, in these circumstances the role of both self-confidence and risk-aversion in the decision to compete might be more relevant. We exploit the fact that in the Italian University academic fields are classified in bibliometric fields - in which scientific productivity is evaluated in relation to bibliometric indicators (109 sub-fields, essentially scientific fields) - and non-bibliometric fields - in which the productivity is evaluated according to other less quantitative indicators (75 sub-fields).

Using this distinction, we analyze whether there is a gender difference in the probability of applying for promotion in bibliometric and non-bibliometric fields. Estimation results are reported in Table 5. We find that females apply less than males especially in non-bibliometric fields in which productivity is harder to measure (columns 1 and 2): females apply for competition 3.7 percentage points less in bibliometric fields and 5.7 percentage points less in non-bibliometric fields.

In column (3) we estimate on the whole sample using an interaction term between Female and Bibliometric Fields and an interaction term between Productivity and Bibliometric Fields (the latter to take into account the possible different impact of productivity among the two areas). We find that in non-bibliometric fields women apply with a probability of 6.6 p.p. less than men, while in bibliometric fields women apply with a lower probability of 3.2 p.p. Furthermore, as expected, we find that the role 
of productivity in bibliometric fields is much more relevant in determining the propensity to enter the competition.

In columns (4) and (5) we estimate separately for Associate and Full professor competitions, finding similar results, although the interaction term Female*Bibliometric Fields is imprecisely estimated for full professor competition. ${ }^{18}$

All in all our results show that, with respect to comparable men, women are more reluctant to compete when they have low productivity or when the measure of productivity is noisier, pointing to an important role of risk-aversion and self-confidence in shaping females' decisions to enter in competitive contexts.

Table 5. Heterogeneous effects in bibliometric and non-bibliometric fields. Probit estimates of the probability of entering the competition

\begin{tabular}{|c|c|c|c|c|c|}
\hline & $\begin{array}{c}(1) \\
\text { Biblio } \\
\text { Fields }\end{array}$ & $\begin{array}{c}(2) \\
\text { Non-Biblio } \\
\text { Fields }\end{array}$ & $\begin{array}{c}\text { (3) } \\
\text { Whole }\end{array}$ & $\begin{array}{c}\text { (4) } \\
\text { Ass. Prof. } \\
\text { Competition }\end{array}$ & $\begin{array}{c}\text { (4) } \\
\text { Full Prof. } \\
\text { Competition }\end{array}$ \\
\hline Female & $\begin{array}{c}-0.037 * * * \\
(0.011)\end{array}$ & $\begin{array}{c}-0.057 * * * \\
(0.013)\end{array}$ & $\begin{array}{c}-0.066^{* * *} \\
(0.014)\end{array}$ & $\begin{array}{l}-0.066^{* * *} * \\
(0.016)\end{array}$ & $\begin{array}{c}-0.072 * * * \\
(0.022)\end{array}$ \\
\hline Productivity & $\begin{array}{c}0.133 * * * \\
(0.008)\end{array}$ & $\begin{array}{c}0.050 * * \\
(0.020)\end{array}$ & $\begin{array}{c}0.051 * * \\
(0.020)\end{array}$ & $\begin{array}{c}0.032 \\
(0.023)\end{array}$ & $\begin{array}{c}0.100 * * * \\
(0.026)\end{array}$ \\
\hline Productivity*Biblio Fields & & & $\begin{array}{c}0.081 * * * \\
(0.021)\end{array}$ & $\begin{array}{c}0.122 * * * \\
(0.027)\end{array}$ & $\begin{array}{c}0.024 \\
(0.028)\end{array}$ \\
\hline Female*Biblio Fields & & & $\begin{array}{l}0.034^{*} \\
(0.018) \\
\end{array}$ & $\begin{array}{l}0.036^{*} \\
(0.021) \\
\end{array}$ & $\begin{array}{c}0.024 \\
(0.030) \\
\end{array}$ \\
\hline $\begin{array}{l}\text { Observations } \\
\text { Pseudo R-squared }\end{array}$ & $\begin{array}{l}5346 \\
0.179\end{array}$ & $\begin{array}{l}3156 \\
0.091\end{array}$ & $\begin{array}{l}8523 \\
0.154\end{array}$ & $\begin{array}{l}5331 \\
0.168\end{array}$ & $\begin{array}{l}3183 \\
0.173\end{array}$ \\
\hline
\end{tabular}

Notes: The Table reports marginal effects of Probit estimates (evaluated at the mean values of the explanatory variables in the sample). The dependent variable is Application. In all specifications we control for individual characteristics and sub-field dummies (not reported) as in specification 3 of Table 3. Standard errors (corrected for heteroskedasticity and allowed for clustering at subfield level) are reported in parentheses. The symbols $* * *, * *, *$ indicate that coefficients are statistically significant, respectively, at the 1,5 , and 10 percent level.

\section{Fear of discrimination and propensity to apply}

The decision of women to apply for the ASN may depend on the chances of promotion faced by women in the past in each field. In the fields in which females have successful careers, it is more likely for young women to have optimistic expectations on the outcome of the ASN and to be encouraged to apply; in contrast, in the fields in which women tend to face a glass ceiling, expectations of promotions will be more pessimistic reducing the females' propensity to apply.

To investigate this issue we build a measure of females' success in each field based on the past promotion rates of women. More precisely, we calculate the Females' Career Success as the ratio, in

\footnotetext{
${ }^{18}$ We have also investigated whether gender differences in entering the competition are heterogeneous across academic fields. We have pooled together similar fields in order to obtain 5 macro-fields: Mathematics and Natural Sciences (Mathematics, Physics, Chemistry, Earth Sciences, Biology), Engineering (Civil Engineering, Industrial and Information Engineering and Architecture), Medicine (Medicine and Agricultural and Veterinary Sciences), Humanities (Literature and History) and Social Sciences (Economics, Law, Sociology and Political Sciences). We find statistically significant gender differences in the probability of entering the competition in Medicine ( 8.9 percentage points), in Humanities and in Social Sciences (about 5 percentage points), while no significant differences emerge in Mathematics, Natural Sciences and Engineering (results not reported).
} 
each sub-field, between the share of females among full professors in 2012 (at the time of application) and the share of females among assistant professors in 2000 (the oldest available data). In this way, we take into account the proportion of females in academic top positions in each field but scale this measure by the proportion of females at the lowest academic positions (neutralizing the fact that women might not be in top positions because of their reluctance to enter in certain fields).

Our variable Females' Career Success has a mean of 0.48, implying that when women represent $50 \%$ of assistant professors in a field, they account for the $24 \%$ of full professors. Females' Career Success has a wide variability both between and within areas. ${ }^{19}$ For instance, within the Economics and Statistics area, the ratio between the share of females among full professors and the share of females among assistant professors ranges from, respectively, 0.34 and 0.36 in Econometrics and Economics, to 0.75 in "Demography and social statistics" and to 0.94 in "Economic Statistics".

To analyze whether women's preferences for competition are related to the females' perceived success in the sub-field, we have estimated equation [1] adding among controls an interaction term between Females' Career Success and Female (we do not include directly Females' Career Success since we are controlling for sub-field dummies). As shown in columns (1) and (2) of Table 6, with and without university dummies among controls, the interaction variable is positive and statistically significant: in a sub-field in which women had very low chances of being promoted to full professors, women show a very low probability of competing (-8.4 percentage points), ceteris paribus. On the other hand, this gender gap in the propensity to apply shrinks to nearly zero when Females' Career Success is equal to one, that is, in fields in which the success of women in promotion has been in line with that of men. Similar results emerge also when we run separate regressions for competitions to full and associate professor positions (although the coefficient on the interaction term is imprecisely estimated, $p$-value $=0.12$, for the associate professor competition).

These results suggest that in fields in which women are perceived as having difficulties in pursuing their careers, women are probably afraid of being discriminated and their probability of applying for the ASN is significantly lower than their male counterparts.

The idea that the lower propensity of women to compete might be driven by the fact that they expect to be discriminated is also supported by some previous works on the Italian promotion system showing substantial gender discrimination in competitions in which male members were predominant in evaluation committees (De Paola and Scoppa, 2015).

\footnotetext{
${ }^{19}$ The Standard Deviation is 0.19 ; the $10^{\text {th }}$ percentile is 0.26 and $90^{\text {th }}$ percentile is 0.75 .
} 
Table 6. Fear of being discriminated? Application and Females' Career Success. Probit estimates of the probability of entering the competition

\begin{tabular}{|c|c|c|c|c|}
\hline & $\begin{array}{c}(1) \\
\text { Whole }\end{array}$ & $\begin{array}{c}(2) \\
\text { Whole }\end{array}$ & $\begin{array}{c}\text { (3) } \\
\text { Ass. Prof. } \\
\text { Competition }\end{array}$ & $\begin{array}{c}\text { (4) } \\
\text { Full Prof. } \\
\text { Competition }\end{array}$ \\
\hline Female & $\begin{array}{c}-0.084 * * * \\
(0.025)\end{array}$ & $\begin{array}{c}-0.086 * * * \\
(0.026)\end{array}$ & $\begin{array}{c}-0.085 * * * \\
(0.029)\end{array}$ & $\begin{array}{c}-0.122 * * * \\
(0.044)\end{array}$ \\
\hline Female* Females' Career Success & $\begin{array}{l}0.082 * \\
(0.047)\end{array}$ & $\begin{array}{l}0.087 * \\
(0.049)\end{array}$ & $\begin{array}{c}0.086 \\
(0.055)\end{array}$ & $\begin{array}{l}0.128 * \\
(0.078)\end{array}$ \\
\hline Productivity & $\begin{array}{c}0.120 * * * \\
(0.008)\end{array}$ & $\begin{array}{c}0.121 * * * \\
(0.008)\end{array}$ & $\begin{array}{c}0.129 * * * \\
(0.013)\end{array}$ & $\begin{array}{c}0.122 * * * \\
(0.011)\end{array}$ \\
\hline $\begin{array}{l}\text { Sub-field dummies (184) } \\
\text { University dummies (93) }\end{array}$ & $\begin{array}{l}\text { YES } \\
\text { NO }\end{array}$ & $\begin{array}{l}\text { YES } \\
\text { YES }\end{array}$ & $\begin{array}{l}\text { YES } \\
\text { YES }\end{array}$ & $\begin{array}{l}\text { YES } \\
\text { YES }\end{array}$ \\
\hline $\begin{array}{l}\text { Observations } \\
\text { Pseudo R-squared }\end{array}$ & $\begin{array}{l}8523 \\
0.150\end{array}$ & $\begin{array}{l}8511 \\
0.159\end{array}$ & $\begin{array}{l}5331 \\
0.160\end{array}$ & $\begin{array}{l}3183 \\
0.173\end{array}$ \\
\hline
\end{tabular}

Notes: The Table reports marginal effects of Probit estimates (evaluated at the mean values of the explanatory variables in the sample). The dependent variable is Application. In all specifications we control for individual characteristics and sub-field dummies (not reported) as in specification 3 of Table 3. Standard errors (corrected for heteroskedasticity and allowed for clustering at subfield level) are reported in parentheses. The symbols $* * *, * * *$ indicate that coefficients are statistically significant, respectively, at the 1,5 , and 10 percent level.

The data at hand allow us also to verify if there has been gender discrimination in the effective outcome of the ASN. The probability of obtaining the ASN is a combination of the probability of applying for the competition and the probability of succeeding in getting the Qualification conditional on having applied. Since it is likely that the variables that affect the probability of promotion are the same variables affecting the individual's decision to apply, it is not possible to implement a selection model. Then, we estimate a Probit model of the probability of success in the competition on the sample of individuals who have applied for (4,369 observations) (see also Bagues, Sylos-Labini and Zinovyeva, 2014). As shown in Table 7, reporting the marginal effects of the Probit estimates, we do not find any difference in the probability of success between males and females (see columns (1) and (2) with and without university dummies among controls). ${ }^{20}$ Similarly, in columns (4) and (5), where we run separate regressions for competitions to position of associate and full professor, we find no gender differences neither for positions to associate professor nor for those to full professor. ${ }^{21}$

The absence of gender discrimination in the ASN outcomes (in contrast to previous findings showing significant gender discrimination) could be explained by the fact that in the context of ASN awarding the qualification has the characteristics of a non-rival goods, since there was no limit to the number of qualification to award in each field.

\footnotetext{
${ }^{20}$ Very similar results are obtained when we use the indicators provided by ASN to measure productivity.

${ }^{21}$ As expected, research productivity has a strong impact on the likelihood of succeeding in the competition. An increase of one standard deviation in Productivity $(\mathrm{SD}=2.1)$ leads to an increase in the probability of success of about 23 percentage points. We also show that Connections play a very relevant role: the probability of success increases of about 8.4 percentage points when a colleague of the department is in the evaluation committee. Using the interaction terms, we do not find differences in the impact of connections between males and females (results not reported).
} 
Table 7. The Probability of Success in the Competition among Applicants. Probit Estimates

\begin{tabular}{|c|c|c|c|c|c|}
\hline & $\begin{array}{c}(1) \\
\text { Whole }\end{array}$ & $\begin{array}{c}(2) \\
\text { Whole }\end{array}$ & $\begin{array}{c}\text { (3) } \\
\text { Whole }\end{array}$ & $\begin{array}{c}\text { (4) } \\
\text { Ass. Prof. } \\
\text { Competition }\end{array}$ & $\begin{array}{c}\text { (5) } \\
\text { Full Prof. } \\
\text { Competition }\end{array}$ \\
\hline Female & $\begin{array}{l}-0.002 \\
(0.019)\end{array}$ & $\begin{array}{c}0.002 \\
(0.019)\end{array}$ & $\begin{array}{c}0.001 \\
(0.019)\end{array}$ & $\begin{array}{l}-0.023 \\
(0.026)\end{array}$ & $\begin{array}{c}0.049 \\
(0.039)\end{array}$ \\
\hline Productivity & $\begin{array}{c}0.113 * * * \\
(0.009)\end{array}$ & $\begin{array}{c}0.109 * * * \\
(0.008)\end{array}$ & $\begin{array}{c}0.111^{* * *} \\
(0.008)\end{array}$ & $\begin{array}{c}0.125 * * * \\
(0.014)\end{array}$ & $\begin{array}{c}0.138 * * * \\
(0.014)\end{array}$ \\
\hline Associate Prof. Comp. & $\begin{array}{c}0.143 * * * \\
(0.022)\end{array}$ & $\begin{array}{c}0.022 \\
(0.026)\end{array}$ & $\begin{array}{c}0.026 \\
(0.026)\end{array}$ & & \\
\hline No tenure & & $\begin{array}{c}-0.093 * * * \\
(0.031)\end{array}$ & $\begin{array}{c}-0.096 * * * \\
(0.033)\end{array}$ & $\begin{array}{l}-0.009 \\
(0.054)\end{array}$ & $\begin{array}{c}-0.052 \\
(0.058)\end{array}$ \\
\hline Potential Connections & & $\begin{array}{c}0.072 * * * \\
(0.018)\end{array}$ & $\begin{array}{c}0.084 * * * \\
(0.020)\end{array}$ & $\begin{array}{c}0.107 * * * \\
(0.027)\end{array}$ & $\begin{array}{c}0.049 \\
(0.043)\end{array}$ \\
\hline Effective Connections & & $\begin{array}{c}0.071 * * * \\
(0.021)\end{array}$ & $\begin{array}{c}0.080 * * * \\
(0.020)\end{array}$ & $\begin{array}{c}0.100 * * * \\
(0.030)\end{array}$ & $\begin{array}{c}0.063 \\
(0.045)\end{array}$ \\
\hline Experience & & $\begin{array}{l}-0.013 * \\
(0.007)\end{array}$ & $\begin{array}{c}-0.015^{* *} \\
(0.007)\end{array}$ & $\begin{array}{l}0.025^{*} \\
(0.014)\end{array}$ & $\begin{array}{l}-0.002 \\
(0.019)\end{array}$ \\
\hline Experience Squared & & $\begin{array}{r}-0.000 \\
(0.000) \\
\end{array}$ & $\begin{array}{r}-0.000 \\
(0.000) \\
\end{array}$ & $\begin{array}{c}-0.003 * * * \\
(0.001) \\
\end{array}$ & $\begin{array}{l}-0.001 \\
(0.001) \\
\end{array}$ \\
\hline $\begin{array}{l}\text { Observations } \\
\text { Pseudo R-squared }\end{array}$ & $\begin{array}{l}4369 \\
0.173\end{array}$ & $\begin{array}{l}4369 \\
0.201\end{array}$ & $\begin{array}{l}4348 \\
0.212\end{array}$ & $\begin{array}{l}2651 \\
0.236\end{array}$ & $\begin{array}{l}1474 \\
0.278\end{array}$ \\
\hline
\end{tabular}

Notes: The Table reports marginal effects of Probit estimates (evaluated at the mean values of the explanatory variables in the sample). The dependent variable is Success. In all specifications we control for sub-field dummies (not reported). Standard errors (corrected for heteroskedasticity and allowed for clustering at subfield level) are reported in parentheses. The symbols $* * *, * *, *$ indicate that coefficients are statistically significant, respectively, at the 1,5 , and 10 percent level.

\section{Concluding remarks}

Recent developments in economics have shown that the observed gender gaps in labor market outcomes could be due, at least in part, to different attitudes towards competition, with women shying away from competitive settings or performing worse than men when in competition. However, most of the existing evidence comes from laboratory experiments (typically employing college students as participants and using small stakes), and it is unclear if individuals' behavior in real settings is similar to the behavior observed in a laboratory.

In this paper we have contributed to fill this gap by providing evidence on female attitudes towards competition in an actual labor market. We have exploited a natural experiment based on the Italian promotion system for associate and full professor positions. Considering a sample of about 8,500 assistant and associate professors working in Italian Universities, we have investigated the existence of gender gaps in the probability of taking part in the competition. After controlling for productivity and a number of individual and field characteristics, we find that females, with respect to their male counterparts, have a lower probability of competing of about 4 percentage points, which amounts to a difference of about 8 percent.

Given the features of the Italian promotion system, we are able to exclude that this difference is due to individual expectations of different performance in competition or to different gender propensity to move to a new department in case of success. The absence of these factors might explain why the gender differences in propensity to compete we find are much smaller compared to those found by Bosquet et al. (2014) when considering the French academic promotions. 
We have considered gender differences in risk aversion and self-confidence as potential drivers of the difference in competitiveness. Since these attitudes are likely to be particularly relevant for low ability individuals, we have investigated differences in the probability of entering competition in relation to individual abilities. We find that the tendency to shy away from competition is peculiar to women in the lower tail of the distribution of scientific productivity, while women in the upper tail behave similar to men. Interestingly, we also find that women are more reluctant to enter competition when the requirements for being promoted are less clear. In fact, our evidence shows that gender differences in the probability of competing are modest in bibliometric fields - in which scientific productivity is more easily measurable - while they become quite relevant in non-bibliometric fields.

We have also investigated women's willingness to enter competition in relation to women's past success in promotions. We find that in fields in which females are perceived as having difficulties in pursuing their careers, women are discouraged to apply for the ASN: the gender gaps in competitiveness could be explained almost entirely by the fact that women are reluctant to apply because of their expectation of being discriminated against.

All in all, we have found significant but small gender differences in competitive attitudes. However, these differences seem to be relevant only for subjects characterized by low levels of productivity and where ability measures are noisier. Furthermore, our results suggest that the reluctance of women to apply for promotion is related to females' career success in the field.

\section{References}

Altonji, J. and Blank, R., (1999), "Race and Gender in the Labor Market" in O. Ashenfelter and D. Card (eds.), Handbook of Labor Economics, 3C, 3143-3259, Amsterdam: North-Holland.

Azmat, G., Petrongolo, B, (2014), "Gender and the Labor Market: What Have We Learned from Field and Lab Experiments?", IZA DP No. 8135, April 2014.

Bagues, M., Sylos-Labini, M., and Zinovyeva, N. (2014), "Do Gender Quotas Pass the Test? Evidence from Academic Evaluations in Italy", Scuola Superiore Sant'Anna, LEM Working Paper Series, 14.

Bertrand M, Hallock K. (2001), "The Gender Gap in Top Corporate Jobs", Industrial and Labor Relation Review, 55, 3-21.

Bertrand, M., (2011), "New Perspectives on Gender", Handbook of Labor Economics, 4b, Amsterdam: North-Holland.

Blau, F., and Kahn, M. (2003), "Understanding International Differences in the Gender Pay Gap", Journal of Labor Economics, 21, 106-144.

Bosquet, C., Combes, P., Garcia-Peñalosa, C. (2014), "Gender and Competition: Evidence from Academic Promotions in France", CESifo Working Paper, No. 4507.

Buser, T., Niederle, M., and Oosterbeek, H. (2014), "Gender, Competitiveness and Career Choices", Quarterly Journal of Economics, 129(3), 1409-1447.

Cotton, C., McIntyre, F. and Price, J. (2013), "Gender Differences in Repeated Competition Evidence from School Math Contests", Journal of Economic Behavior and Organization, 86.

Croson, R., and U. Gneezy, (2009), "Gender Differences in Preferences." Journal of Economic Literature, 47 (2), 448-74.

De Paola, M., and Scoppa, V., (2015), "Gender Discrimination and Evaluators' Gender: Evidence from the Italian Academia", Economica, 82 (325), 162-188. 
De Paola, M., Gioia F. and Scoppa, V. (2014), "Are Females Scared of Competing with Males? Results from a Field Experiment.” IZA Discussion Paper No. 8021.

Delfgaauw, J. Dur, R., Sol, J. and Verbeke, W., (2013), "Tournament Incentives in the Field: Gender Differences in the Workplace", Journal of Labor Economics, 31(2), 305-326.

Flory, J., Leibbrandt, A. and List, J., (2015), "Do Competitive Work Places Deter Female Workers? A Large-Scale Natural Field Experiment on Gender Differences in Job-Entry Decisions", Review of Economic Studies, 82, 122-155.

Gneezy, U., Niederle, M. and Rustichini, A., (2003), "Performance in competitive environments: gender differences", Quarterly Journal of Economics, 118, 1049-1074.

Gneezy, U. and Rustichini, A., (2004), "Gender and competition at a young age", American Economic Review, 94 (2), 377-381.

Jurajda S, Munich D. (2011), "Gender Gap in Performance under Competitive Pressure: Admission to Czech Universities”, American Economic Review: Papers \& Proceedings 2011, 101(3), 514518.

Lavy, V. (2012). "Gender Differences in Market Competitiveness in a Real Workplace: Evidence from Performance-based Pay Tournaments among Teachers", Economic Journal, 123(569), 540573.

Niederle, M. and Vesterlund, L. (2007), "Do Women Shy Away from Competition? Do men Compete Too Much?” Quarterly Journal of Economics, 122 (3), 1067-1101.

Niederle, M. and Vesterlund, L. (2011), "Gender and Competition", Annual Review of Economics, 3, 601-630.

Ors, E., Palomino and F. Peyrache, E., (2013), "Performance Gender Gap: Does Competition Matter?", Journal of Labor Economics, 31(3), 443-499.

Price, C. (2010), "Do Women Shy Away From Competition? Do Men Compete Too Much? A (Failed) Replication", Working Paper University of Southern Indiana.

Sandberg, S. (2013), Lean In: Women, Work, and the Will to Lead: BookpointLLC.

Sutter, M., Glätzle-Rützler, D. (2015), "Gender differences in the willingness to compete emerge early in life and persist", Management Science, forthcoming. 


\section{APPENDIX. Descriptive statistics. Breakdown for type of position}

Table A. Descriptive Statistics. Potential Candidates for Associate Professor Positions

\begin{tabular}{|c|c|c|c|c|c|}
\hline & Mean & St. Dev. & Min & Max & Obs. \\
\hline Application & 0.526 & 0.499 & 0 & 1 & 5331 \\
\hline Female & 0.449 & 0.497 & 0 & 1 & 5331 \\
\hline North-West & 0.238 & 0.426 & 0 & 1 & 5331 \\
\hline North-East & 0.182 & 0.386 & 0 & 1 & 5331 \\
\hline Centre & 0.289 & 0.453 & 0 & 1 & 5331 \\
\hline South & 0.173 & 0.378 & 0 & 1 & 5331 \\
\hline Islands & 0.117 & 0.322 & 0 & 1 & 5331 \\
\hline No tenure & 0.221 & 0.415 & 0 & 1 & 5331 \\
\hline Potential Connections & 0.648 & 0.478 & 0 & 1 & 5331 \\
\hline Effective Connections & 0.176 & 0.381 & 0 & 1 & 5331 \\
\hline Experience & 7.706 & 5.181 & 0 & 17 & 5331 \\
\hline Scientific Field & 0.640 & 0.480 & 0 & 1 & 5331 \\
\hline Productivity & -0.263 & 1.611 & -1.746 & 8.580 & 5331 \\
\hline Papers & 28.833 & 31.337 & 0 & 202 & 5331 \\
\hline Citations & 355.714 & 691.634 & 0 & 4965 & 5331 \\
\hline h-index & 6.747 & 6.619 & 0 & 35 & 5331 \\
\hline g-index & 12.082 & 12.458 & 0 & 66 & 5331 \\
\hline
\end{tabular}

Table B. Descriptive Statistics. Potential Candidates for Full Professor Positions

\begin{tabular}{|c|c|c|c|c|c|}
\hline & Mean & St. Dev. & Min & Max & Obs. \\
\hline Application & 0.504 & 0.500 & 0 & 1 & 3192 \\
\hline Female & 0.342 & 0.475 & 0 & 1 & 3192 \\
\hline North-West & 0.235 & 0.424 & 0 & 1 & 3192 \\
\hline North-East & 0.192 & 0.394 & 0 & 1 & 3192 \\
\hline Centre & 0.277 & 0.448 & 0 & 1 & 3192 \\
\hline South & 0.191 & 0.393 & 0 & 1 & 3192 \\
\hline Islands & 0.105 & 0.306 & 0 & 1 & 3192 \\
\hline No tenure & 0.117 & 0.322 & 0 & 1 & 3192 \\
\hline Potential Connections & 0.635 & 0.482 & 0 & 1 & 3192 \\
\hline Effective Connections & 0.175 & 0.380 & 0 & 1 & 3192 \\
\hline Experience & 14.787 & 5.379 & 0 & 22 & 3192 \\
\hline Scientific Field & 0.641 & 0.480 & 0 & 1 & 3192 \\
\hline Productivity & 0.374 & 2.139 & -1.746 & 8.580 & 3192 \\
\hline Papers & 42.447 & 42.103 & 0 & 202 & 3192 \\
\hline Citations & 590.424 & 988.711 & 0 & 4965 & 3192 \\
\hline h-index & 9.187 & 8.360 & 0 & 35 & 3192 \\
\hline g-index & 16.383 & 15.523 & 0 & 66 & 3192 \\
\hline
\end{tabular}

